CATALLAXY

Volume 2 Issue 1 June 2017

e-ISSN 2544-090X

¿ www.catallaxy.pl

Oryginalny artykut naukowy

otrzymano: 17.05.2017 / zaakceptowano: 28.06.2017 / opublikowano online: 30.06 .2017

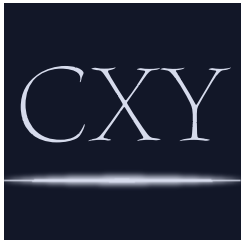

()ㅜㅇㅛ

Olejnik, Ł.W. (2017). Determinanty poparcia dla członkostwa w Unii Europejskiej. Catallaxy, 2(1): 5-12. doi:10.24136/ cxy.v2i1.1.

\title{
Determinanty poparcia dla członkostwa w Unii Europejskiej
}

\author{
EUKASZ WIKTOR OLEJNIK \\ Szkoła Gtowna Handlowa w Warszawie, al. Niepodległości 162.02-554 Warszawa, Polska \\ 曰1056801@student.sgh.waw.pl \\ (iD) orcid.org/0000-0002-4250-961X
}

\begin{abstract}
Abstrakt
Motywacja: Głównym motywem wyboru tematu niniejszego artykułu było wyjaśnienie przyczyn wyjścia Wielkiej Brytanii z Unii Europejskiej (UE) i ukazania zmian postaw politycznych obywateli państw członkowskich oraz zjawisk społecznych wplywających na postrzeganie integracji międzynarodowej. Drugim motywem była próba zbadania wpływu sytuacji gospodarczej na wybory polityczne obywateli.

Cel: Celem artykułu jest identyfikacja wpływu zmiennych makroekonomicznych na poparcie dla członkostwa w UE. Wyniki: Na podstawie zaprezentowanego modelu ekonometrycznego wykazano, że wpływ na postrzeganie instytucji unijnych mają: sytuacja ekonomiczna w danym państwie, napływ imigrantów i czynniki polityczne. Wpływ takich czynników, jak: nierówności społeczne i konsolidacja fiskalna, okazał się nieistotny statystycznie.
\end{abstract}

Stowa kluczowe: integracja europejska; badania sondażowe; poparcie dla Unii Europejskiej JEL: C23; F55; F68

\section{Wprowadzenie}

Od momentu ogłoszenia wyników referendum na temat członkostwa Wielkiej Brytanii w Unii Europejskiej (UE), wielu polityków, publicystów i osób zajmujących się naukami społecznymi próbuje wyjaśnić przyczyny spadku poparcia dla integracji europejskiej. W wielu państwach rozpoczęła się dyskusja na temat korzyści i strat wynikających z członkostwa w UE, dlatego warto podjąć próbę weryfikacji niektórych twierdzeń na temat przyczyn zmian stosunku obywateli państw unijnych do tej instytucji.

W debacie publicznej pada wiele opinii, które często bywają sprzeczne. Według niektórych $z$ nich, za spadek poparcia dla człon- kostwa w UE odpowiadają cięcia budżetowe i zbyt małe wydatki socjalne $\mathrm{w}$ państwach unijnych, które powodują niepokoje społeczne i sprzeciw wobec globalizacji (Mauldin, 2016). Według innej opinii, przyczyną spadku poparcia dla członkostwa w UE są zbyt duże wydatki socjalne i rozrośnięta biurokracja, które hamują wzrost gospodarczy i stają się przyczyną spadku konkurencyjności gospodarek państw unijnych (Rodionova, 2016). Stosunkowo często wskazuje się unijnych urzędników, jako winnych spadku poparcia dla integracji europejskiej i braku demokratycznego mandatu wielu z nich (Krastev, 2016). W niektórych państwach pojawiają się oskarżenia o wprowadzanie projektów motywowanych ideologicznie, prowadzących jednocześnie do utraty 
tożsamości narodowych wśród obywateli państw członkowskich (Joffe, 2016).

$\mathrm{W}$ artykułach publicystycznych i pracach naukowych można zaobserwować wiele możliwych wyjaśnień przyczyn spadku poparcia dla członkostwa w UE, dlatego warto podjąć próbę identyfikacji rzeczywistych czynników wpływających, pozytywnie lub negatywnie, na akceptację dla postępującej integracji europejskiej. W niniejszym artykule przedstawiono model ekonometryczny, którego celem jest próba wyjaśnienia tego zjawiska.

Celem artykułu jest identyfikacja wpływu zmiennych makroekonomicznych na poparcie dla członkostwa w UE.

W Sekcji 2. zawarto przegląd dotychczasowych badań na temat przyczyn zmian poparcia dla członkostwa w UE. W Sekcji 3. umieszczono opis danych, które posłużyły do stworzenia modelu ekonometrycznego omówionego następnie w Sekcji 4. W Sekcji 5. podsumowano wyniki badania.

\section{Przegląd literatury}

Pierwsze analizy czynników wpływających na poparcie dla integracji europejskiej powstały w latach 90. XX wieku. W pracy R.C. Eichenberg i R.J. Dalton (1993), znaleźć można analizę wpływu handlu między państwami członkowskimi oraz transferów finansowych do państw członkowskich na poparcie dla postępującej integracji europejskiej. Zgodnie $z$ oczekiwaniami, wykazano pozytywny wpływ rozwoju handlu zagranicznego oraz napływu funduszy unijnych do państw członkowskich na stosunek do UE, jako organizacji.

Teza o wpływie transferów środków do państw członkowskich znalazła również potwierdzenie $w$ badaniach przeprowadzonych przez C.J. Anderson i M.S. Reichert (1995). $\mathrm{Na}$ podstawie wyników sondażu Eurobarometer $z$ trzech różnych lat, udowodniono pozytywny wpływ napływu środków unijnych na średni poziom poparcia dla instytucji unijnych. Wykazano również statystycznie istotne różnice $\mathrm{w}$ obrębie grup ludności. Stosunkowo wysokie poparcie notowano $\mathrm{w} \mathrm{du}$ żych miastach, natomiast niskie $\mathrm{w}$ mniejszych miejscowościach. Ponadto, wpływ miała również charakterystyka badanych. Poparcie dla członkostwa w UE wyrażały osoby lepiej wykształcone i uzyskujące wysokie dochody, natomiast brak poparcia odnotowano wśród osób gorzej wykształconych i uzyskujących mniejszy dochód.

Podobne wyniki przedstawiono $\mathrm{w}$ pracy M.J. Gabel (1998). Na podstawie modelu probitowego oszacowano wpływ wykształcenia i zarobków na poparcie dla członkostwa w UE. Estymacja parametrów modelu pozwoliła na wykazanie, że osoby tworzące wyższy kapitał ludzki istotnie częściej popierają integrację europejską. Ponadto, prawdopodobieństwo odpowiedzi twierdzącej na pytanie o osobiste korzyści z członkostwa w UE, wzrastało wraz ze wzrostem zarobków. Bezwzględna wartość zarobków nie miała większego znaczenia, liczyły się natomiast wartości względne. Osoby zarabiające względnie mniej, w stosunku do najbogatszej części społeczeństwa, były mniej skłonne do popierania działalności instytucji unijnych. Stanowi to potwierdzenie tezy o wpływie czynników społecznych na stosunek do organizacji międzynarodowych.

Podobne badanie dla państw UE-27 znaleźć można w pracy K. Jacquier (2012). Dokonanoestymacji parametrów uporządkowanego modelu logitowego, w którym za zmienną objaśnianą przyjęto wyniki sondaży. Zgodnie $z$ przewidywaniami, wyższe poparcie dla członkostwa w UE było determinowane przez wyższe zarobki i wyższe wykształcenie. Natomiast, relatywnie słaby poziom kapitału ludzkiego, względnie niższe zarobki i członkostwo w związkach zawodowych, wpływały negatywnie na zmienną objaśnianą. Nie odnotowano istotnej różnicy w poparciu między osobami pracującymi a osobami bezrobotnymi. Statystycznie istotne, wyższe poparcie dla członkostwa w UE odnotowano w byłych państwach postkomunistycznych, co można wyjaśnić stosunkowo dużym strumieniem funduszy europejskich napływających do tych państw. W pracy J. Bolstad (2014), wykazano, że poparcie dla UE było wyższe nie tylko $\mathrm{w}$ państwach postkomunistycznych, ale różniło się również w obrębie państw UE-15. 
W sześciu państwach założycielskich UE, odnotowano statystycznie istotne, wyższe poparcie dla integracji europejskiej.

Próba wskazania determinant poparcia dla instytucji UE została podjęta przez C. Tanasoiu i C. Colonescu (2008). Na podstawie mikrodanych, uzyskanych $z$ badania sondażowego, zbadano determinanty poparcia dla UE w Bułgarii, przy użyciu liniowego modelu prawdopodobieństwa. Pozytywny wpływ na tę zmienną miał wysoki poziom zaufania do rządu własnego państwa oraz pozytywny stosunek do demokracji jako ustroju. Prawdopodobieństwo zadeklarowania poparcia wzrastało również wśród najmłodszych respondentów, kobiet i osób z relatywnie wysokim wykształceniem.

Podobne wyniki znaleźć można w pracy A. Folsz i G. Toka (2006, ss. 145-163). W przypadku Węgier, w latach 1991-2003, poparcie dla członkostwa w UE było wyższe wśród osób młodszych, lepiej wykształconych i zatrudnionych $w$ usługach, natomiast znacząco niższe, wśród emerytów i rolników. Ponadto, odnotowano istotną korelację między poglądami politycznymi badanych a poparciem dla członkostwa Węgier w UE. Poparcie deklarowały, w zdecydowanej większości, wszystkie grupy elektoratu, poza elektoratami partii określonych przez autorów mianem "ekstremistycznych".

Istotny wkład $\mathrm{w}$ analizę przyczyn poparcia dla instytucji UE wnosi badanie O. Doyle i J. Fidrmuc (2006). Na podstawie wyników siedmiu referendów akcesyjnych, które odbyły się $\mathrm{w}$ państwach przyjętych do UE w 2004 roku, zidentyfikowano czynniki ekonomiczne, które wpłynęły na decyzję wyborców. Wyższe poparcie dla członkostwa $w$ UE odnotowano w regionach $z$ wyższym odsetkiem osób zatrudnionych w usługach i wyższym bezrobociem, natomiast niższe $w$ regionach $z$ dużym odsetkiem osób zatrudnionych w rolnictwie. Autorzy badania wskazują, że rolnicy mogli obawiać się konkurencji ze strony innych państw UE, natomiast bezrobotni mogli liczyć na napływ inwestycji i rozwój ich regionów, dzięki funduszom strukturalnym
$\mathrm{Na}$ podstawie przytoczonych badań można wyciągnąć wniosek, że wyższe poparcie dla UE deklarowały osoby odnoszące stosunkowo największe korzyści z członkostwa ich państw $w$ tej organizacji. Zdecydowana większość badań, wykonywana była na podstawie mikrodanych i wyników sondaży, co stanowi pewne ograniczenie. Na ich podstawie trudno określić zmiany poparcia wśród wszystkich państw UE oraz zmianę tego zjawiska $\mathrm{w}$ czasie. Ponadto, $\mathrm{z}$ reguły badano wpływ zmiennych socjoekonomicznych na poparcie dla instytucji unijnych, pomijano natomiast zmienne typowo makroekonomiczne. $\mathrm{Ze}$ względu na istniejącą lukę w badaniach, zdecydowano się na stworzenie modelu w oparciu o dane panelowe dla wszystkich państw UE obejmujące lata 2001-2015. Celem była ocena wpływu efektów czasowych oraz zmiennych makroekonomicznych na pozytywny stosunek do instytucji unijnych.

\section{Dane}

Za zmienną objaśnianą $\mathrm{w}$ modelu przyjęto ocenę postrzegania UE w danym roku. Komisja Europejska, dwa razy w roku, zleca badania opinii publicznej we wszystkich państwach członkowskich, których wyniki są następnie publikowane. Od 2001 roku badania Eurobarometer odbywają się cyklicznie. Ponadto, nie doszło do zmian $w$ metodologii prowadzenia sondaży. W każdym $z$ nich zadano pytanie "Czy Pani/Pan postrzega UE zdecydowanie dobrze, raczej dobrze, neutralnie, raczej źle, czy zdecydowanie źle?". Odsetek odpowiedzi „zdecydowanie dobrze” i „raczej dobrze” zsumowano i użyto jako zmienną objaśnianą (zmienna poparcie). Jako zmienną objaśnianą wykorzystano dane $z$ pierwszego półrocza każdego roku.

Jako potencjalne determinanty pozytywnego postrzegania UE, wytypowano zmienne makroekonomiczne oraz zmienną określającą liczbę imigrantów w danym państwie. Za zmienne określające sytuację makroekonomiczną przyjęto stopy wzrostu PKB w danym roku w stosunku do roku poprzedniego (zmienna wzrost PKB) oraz stosunek wartości 
eksportu do PKB (zmienna eksport). Z przeprowadzonego w Sekcji 2. przeglądu literatury wynika, że poparcie dla członkostwa w UE było niższe wśród osób o relatywnie niższych dochodach w stosunku do najbogatszej części społeczeństwa, dlatego uwzględniono wskaźnik nierówności w dystrybucji dochodów w danym państwie, tzn. wskaźnik Giniego (zmienna gini), który przyjmuje poziom od 0 (idealna równość) do 1 (jedna osoba otrzymuje cały dochód w gospodarce). Pominięto kwestię bezrobocia, gdyż w przytoczonych publikacjach, nie odnotowano istotnego wpływu bezrobocia na poparcie dla integracji europejskiej. W wielu publikacjach wskazuje się również napływ imigrantów, jako potencjalną przyczynę spadku poparcia dla członkostwa danego państwa w UE. Dlatego włączono do modelu zmienną imigracja, która jest stosunkiem liczby imigrantów do ogólnej populacji danego państwa.

Jako jedną z przyczyn niechęci wobec instytucji unijnych $\mathrm{w}$ państwach śródziemnomorskich, wskazuje się obowiązujące kryteria konwergencji z Maastricht i działania organizacji międzynarodowych, które w czasie kryzysu fiskalnego po 2009 roku, wymusiły cięcia budżetowe i konsolidację fiskalną w państwach o niestabilnych finansach publicznych. Zdecydowano się na stworzenie zmiennej konsolidacja, która stanowi miarę konsolidacji fiskalnej w danych państwach. Przyjmuje ona wartości wyrażone w p.p., opisane wzorem (1):

$$
\begin{aligned}
& \text { konsolidacja }_{i, t}= \\
& =\left\{\begin{array}{c}
\operatorname{def}_{i, t}-\operatorname{def}_{i, t-1}, \text { dla def }_{i, t-1} \geq 3 \% \\
0, \quad \text { dla def } f_{i, t-1}<3 \%
\end{array}\right.
\end{aligned}
$$

gdzie:

def $f_{i, t}$ - deficyt sektora finansów publicznych $w i$-tym państwie $w$ stosunku do PKB w okresie $t(w \%)$;

def $_{i, t-1}$ - deficyt sektora finansów publicznych $w i$-tym państwie $w$ stosunku do PKB w okresie t-1 (w\%).

Źródłem wszystkich danych, potrzebnych do stworzenia zmiennych objaśniających był Eurostat (2017). Statystyki opisowe oraz opis zmiennych przedstawiono $\mathrm{w}$ tabeli 1 .

\section{Model}

Zmienne, opisane w Sekcji 3., posłużyły do stworzenia modelu ekonometrycznego. Ze względu na charakter danych, zdecydowano się na stworzenie modelu w oparciu o dane panelowe. Wykorzystano w tym celu obserwacje $z$ dwudziestu ośmiu państw członkowskich UE $z$ lat 2001-2015, przy czym uwzględniono tylko pełne lata członkostwa. W przypadku państw, które dołączyły do UE 1 maja 2004 roku, zakres czasowy obejmuje lata 20052015, dla Rumunii i Bułgarii lata 2007-2015, natomiast dla Chorwacji lata 2014-2015.

$\mathrm{Na}$ podstawie wartości statystyki testu Hausmana, uznano za konieczne wykorzystanie modelu $z$ efektami stałymi (fixed effects). Do szacowania modelu dwukierunkowego wykorzystano metodę within. Zdecydowano się na włączenie do modelu efektów czasowych, dlatego równanie modelu przyjmuje postać opisaną wzorem (2):

$$
Y_{i, t}=\alpha_{i}+\beta_{i} X_{i, t}+\theta_{t}+\varepsilon_{i, t},
$$

gdzie:

$Y_{i, t}$ - odsetek obywateli $i$-tego państwa deklarujących poparcie dla członkostwa ich państwa w UE w sondażu Eurobarometer (w\%) w okresie $t$;

$X_{i, t}$ - zmienne objaśniane (tj. wzrost PKB, eksport, imigracja, gini, konsolidacja) dla $i$-tego państwa $w$ okresie $t$ (opis zmiennych zawarto $w$ tabeli 1 .);

$\theta_{t}$ - efekty czasowe w okresie $t$;

$\alpha_{i}$ - efekty indywidualne dla $i$-tego państwa;

$\beta_{i}-$ parametry modelu dla $i$-tego państwa;

$\varepsilon_{i, t}$ - składnik losowy dla $i$-tego państwa w okresie $t$.

Wyniki estymacji modelu zamieszczono $\mathrm{w}$ tabeli 2. Zgodnie $z$ oczekiwaniami, parametry przy zmiennych makroekonomicznych (tj. zmiennej wzrost PKB i eksport), okazały się istotne statystycznie i większe od zera. Poprawa sytuacji makroekonomicznej wpływała na wzrost ocen funkcjonowania instytucji unijnych, podobnie, jak wzrost stopnia otwartości gospodarki. Wzrost eksportu 
oznacza wzrost liczby kontaktów handlowych między państwami członkowskimi oraz możliwość doświadczenia skutków zniesienia ceł $\mathrm{w}$ wymianie międzynarodowej, $w$ ramach unii celnej. Indywidualne korzyści z integracji europejskiej mogą stanowić jedną z przyczyn poprawy ocen instytucji unijnych.

Parametry znajdujące się przy zmiennych odzwierciedlających stopień konsolidacji fiskalnej (zmienna konsolidacja), i skalę nierówności $\mathrm{w}$ dystrybucji dochodów $\mathrm{w}$ danym państwie (zmienna gini), okazały się nieistotne statystycznie. Na tej podstawie można wyciągnąć wniosek, że czynniki te nie wpływały $\mathrm{w}$ istotnym stopniu na stosunek do integracji europejskiej.

Stosunkowo dużym zaskoczeniem jest poziom parametru przy zmiennej opisującej stosunek liczby imigrantów do populacji danego państwa (zmienna imigracja). Okazal się on dodatni, istotny statystycznie i stosunkowo wysoki. Wzrost udziału liczby imigrantów w liczbie mieszkańców ogółem danego państwa o 1 p.p. powodowal wzrost poparcia dla integracji europejskiej o 8,2 p.p. Stanowi to zaprzeczenie opinii zakładających, że główną przyczyną spadku poparcia dla członkostwa w UE jest wzrost liczby imigrantów. Prawdopodobną przyczyną mogła być możliwość wyjazdu na zagraniczne studia lub możliwość zatrudnienia obywateli innych państw członkowskich. Innym, możliwym wyjaśnieniem było istnienie zmiennej ukrytej, która wpływa zarówno na poprawę stosunku do UE, jak i na wzrost liczby imigrantów w danym państwie. Wpływ wzrostu liczby migrantów na stosunek mieszkańców tego państwa do instytucji unijnych wymaga dalszych badań.

Analiza parametrów przy zmiennych opisujących efekty czasowe pozwala na wyciągnięcie dwóch wniosków. Po pierwsze, istotny statystycznie wzrost odsetka osób deklarujących pozytywny stosunek do instytucji unijnych, w stosunku do 2001 roku, miał miejsce w latach 2002-2003, 2007 roku oraz w latach 2011-2015. Lata 2002-2003 to okres przed akcesją nowych państw do UE. W kolejnych latach można zaobserwować brak istotności statystycznej parametrów opisujących zmienne czasowe. Lata 2006-2009 to okres debat na temat eurokonstytucji i ewentualnej ratyfikacji Traktatu lizbońskiego $\mathrm{w}$ wielu państwach europejskich. Test istotności parametrów oraz znaki przy parametrach, wskazują brak negatywnego wpływu tych debat na stosunek do UE. Znaczącą zmianę opinii społecznej można zaobserwować po 2011 roku. Był to okres kryzysu bankowego i kryzysu fiskalnego w wielu państwach członkowskich. Instytucje unijne aktywnie uczestniczyły w kształtowaniu polityki gospodarczej państw strefy euro, co mogło wpłynąć na stosunek obywateli tych państw do organów unijnych. Należy również zauważyć, że największe spadki pozytywnych ocen wystąpiły w 2013 roku, w kolejnych latach nastąpiła poprawa stosunku mieszkańców państw unijnych do samej UE.

\section{Wnioski}

Modelowanie zjawisk społecznych stanowi trudne zadanie od strony statystyczno-ekonometrycznej, gdyż istnieje bardzo duża liczba potencjalnych przyczyn, które wpływają na wyniki sondaży. Nie istnieją metody pozwalające na dokładne skwantyfikowanie wpływu biurokracji, regulacji i charyzmy poszczególnych polityków. Wpływ na stosunek do instytucji unijnych może mieć bardzo wiele, niemożliwych do uwzględnienia $\mathrm{w}$ modelu czynników.

Przedstawione w Sekcji 4. wyniki estymacji modelu (2), pozwalają jednak na wyciągnięcie wniosków, które umożliwiają weryfikację niektórych tez publicystycznych. Nie odnotowano istotnego wpływu konsolidacji fiskalnej w państwach Europy Południowej na stosunek obywateli tych państw do instytucji unijnych. Stosunek ten, nie zależy również od zmian wskaźnika nierówności w dystrybucji dochodów. Na podstawie modelu (2) i jego weryfikacji można również uznać za nieprawdziwą tezę o negatywnym wpływie Traktatu lizbońskiego na stosunek mieszkańców państw unijnych do integracji europejskiej.

Jak wspomniano, istnieje szereg trudności towarzyszących analizie zmian poparcia dla członkostwa w UE, związanych $z$ mode- 
lowaniem zjawisk społecznych. Jednak powinny być one kontynuowane, gdyż pozwalają na weryfikację wielu tez obecnych $w$ publikacjach naukowych lub artykułach publicystycznych. Na podstawie przeprowadzonej analizy można wywnioskować, że sytuacja ekonomiczna wpływa na zmiany poparcia dla instytucji unijnych, jednak stosunkowo istotne mogą być również lokalne uwarunkowania i czynniki czysto polityczne.

\section{Bibliografia}

Anderson, C.J., i Reichert, M.S. (1995). Economic benefits and support for membership in the EU: a cross-national analysis. Journal of Public Policy, 15(3). doi:10.1017/S0143814X00010035.

Bolstad, J. (2014). Dynamics of European integration: Public opinion in the core and periphery. European Union Politics, 16(1). doi:10.1177/1465116514551303.

Doyle, O., i Fidrmuc, J. (2006). Who favors enlargement?: Determinants of support for EU membership in the candidate countries' referenda. European Journal of Political Economy, 22(2). doi:10.1016/j.ejpoleco.2005.09.008.

Eichenberg, R.C., i Dalton, R.J. (1993). Europeans and the European Community: the dynamics of public support for European integration. International Organization, 47(4). doi:10.1017/ S0020818300028083.

Eurostat. (2017). Pobrane 24.04.2017 z http:// ec.europa.eu/eurostat.

Folsz, A. i Toka, G. (2006). Determinants of support for EU membership in Hungary. W: R. Rohrschneider i S. Whitefield (red.), Public opinion, party competition, and the European Union in Post-communist Europe. New York: Palgrave Macmillan.
Gabel, M.J. (1998). Economic integration and mass politics: market liberalization and public attitudes in the European Union. American Journal of Political Science, 42(3). doi:10.2307/2991736.

Jacquier, K. (2012). Public support for European integration: a comparative analysis. Documents de travail du CES, 88.

Joffe, J. (2016). Historic, dangerous decision. Pobrane 24.04.2017 z http://www.politico.eu.

Krastev, I. (2016). Political elites lost Europe. Pobrane 24.04.2017 z http://www.politico.eu.

Mauldin, J. (2016). Three reasons why Brits voted for Brexit. Pobrane 24.04.2017 $z$ http://www.forbes.com.

Rodionova, Z. (2016). EU referendum: The business arguments for and against UK membership. Pobrane 24.04.2017 $z$ http://www.independent. co.uk.

Tanasoiu, C. i Colonescu, C. (2008). Determinants of support for European integration: the case of Bulgaria. European Union Politics, 9(3). doi:10.1177/1465116508093489.

\section{Informacje uzupetniające}

Wkład autorski: autor zaakceptował ostateczną wersję artykułu.

Podziękowania autorskie: autor składa podziękowania za pomoc w przygotowaniu artykułu następującym osobom: Dorocie Ścibisz i dr. Tymonowi Stoczyńskiemu.

Uwagi: wyniki badania byly zaprezentowane w innej formie, tj. wystąpienia na VII Ogólnopolskiej Konferencji Naukowej Problemy gospodarki światowej (Toruń, 28.04.2017). 


\section{Aneks}

Tabela 1.

Statystyki opisowe zmiennych przyjętych w modelu (2)

\begin{tabular}{|c|c|c|c|c|c|}
\hline Zmienna & Opis & Maksimum & Mediana & $\begin{array}{l}\text { Odchylenie } \\
\text { standardowe }\end{array}$ & Minimum \\
\hline poparcie & $\begin{array}{l}\text { odsetek obywateli danego państwa deklarujących } \\
\text { poparcie dla członkostwa ich państwa w UE } \\
\text { w sondażu Eurobarometer (w \%) }\end{array}$ & 0,7300 & 0,4295 & 0,1209 & 0,1600 \\
\hline wzrost $P K B$ & $\begin{array}{c}\text { stopa wzrostu PKB per capita w parytecie sity } \\
\text { nabywczej w danym państwie (w\%) }\end{array}$ & 0,1626 & 0,0185 & 0,0383 & $-0,1481$ \\
\hline eksport & $\begin{array}{l}\text { stosunek wartości eksportu danego państwa do } \\
\qquad \mathrm{PKB}(w \%)\end{array}$ & 0,9490 & 0,3948 & 0,2180 & 0,0473 \\
\hline imigracja & $\begin{array}{c}\text { stosunek liczby imigrantów do liczby ludności } \\
\text { danego państwa (w \%) }\end{array}$ & 0,0431 & 0,0089 & 0,0075 & 0,0002 \\
\hline $\operatorname{gini}$ & $\begin{array}{l}\text { współczynnik nierówności dochodowych Giniego } \\
\text { w danym państwie }\end{array}$ & 38,9000 & 29,6147 & 4,0047 & 22,0000 \\
\hline konsolidacja & $\begin{array}{l}\text { skala konsolidacji fiskalnej obliczona według wzoru } \\
\text { (1) (w\%) }\end{array}$ & 19,5000 & 0,7724 & 1,8270 & 0,0000 \\
\hline
\end{tabular}

Źródło: Opracowanie własne na podstawie danych Eurostat (2017). 
Tabela 2.

Wyniki estymacji modelu (2)

\begin{tabular}{|c|c|c|c|}
\hline Zmienna & Ocena parametru & Błąd standardowy & Wartość p \\
\hline stata & 0,2487 & 0,0829 & 0,0030 \\
\hline wzrost $P K B$ & 0,3756 & 0,1275 & 0,0030 \\
\hline eksport & 0,1405 & 0,0551 & 0,0110 \\
\hline imigracja & 8,2331 & 1,1336 & 0,0000 \\
\hline $\operatorname{gini}$ & 0,0025 & 0,0026 & 0,3350 \\
\hline konsolidacja & $-0,0022$ & 0,0019 & 0,2580 \\
\hline 2002 & 0,0604 & 0,0208 & 0,0040 \\
\hline 2003 & 0,0396 & 0,0209 & 0,0590 \\
\hline 2004 & 0,0047 & 0,0209 & 0,8230 \\
\hline 2005 & 0,0208 & 0,0193 & 0,2810 \\
\hline 2006 & 0,0306 & 0,0193 & 0,1130 \\
\hline 2007 & 0,0373 & 0,0191 & 0,0510 \\
\hline 2008 & 0,0253 & 0,0192 & 0,1880 \\
\hline 2009 & 0,0328 & 0,0219 & 0,1350 \\
\hline 2010 & $-0,0282$ & 0,0190 & 0,1380 \\
\hline 2011 & $-0,0567$ & 0,0201 & 0,0050 \\
\hline 2012 & $-0,1394$ & 0,0204 & 0,0000 \\
\hline 2013 & $-0,1513$ & 0,0204 & 0,0000 \\
\hline 2014 & $-0,1087$ & 0,0202 & 0,0000 \\
\hline \multirow[t]{2}{*}{2015} & $-0,0584$ & 0,0206 & 0,0050 \\
\hline & & Poziom & Wartość p \\
\hline \multicolumn{2}{|c|}{$R^{2}$ wewnątrzgrupowy } & 0,6310 & - \\
\hline \multicolumn{2}{|c|}{$R^{2}$ międzygrupowy } & 0,0395 & - \\
\hline \multicolumn{2}{|c|}{ współczynnik rho } & 0,7304 & - \\
\hline \multicolumn{2}{|c|}{ test Walda zróżnicowania efektów indywidualnych } & 22,4400 & 0,000 \\
\hline
\end{tabular}

Źródło: Opracowanie własne na podstawie danych Eurostat (2017).

Determinants of support for European Union membership

\begin{abstract}
Motivation: The main motivation for choosing the subject of this article was to explain the reasons for the United Kingdom's departure from the European Union (EU) and to show the changes in political attitudes of the Member States citizens as well as the social phenomena affecting the perception of international integration. The second motive was an attempt to study the impact of economic situation on citizens' political choices.

Aim: The aim of this article is to identify the impact of macroeconomic variables on the support for EU membership. Results: Based on the presented econometric model, it was shown that the perception of the EU institutions is affected by: the economic situation in a given country, the influx of immigrants, and political factors. The impact of such factors as: the social inequalities and the fiscal consolidation was statistically insignificant.
\end{abstract}

Keywords: European integration; survey research; support for the European Union JEL: C23; F55; F68 